acta universitatis lodziensis

2009

Folia Biologica et Oecologica 5: 5-19

(Acta Univ., Lodz, Folia Biol. et Oecol.)

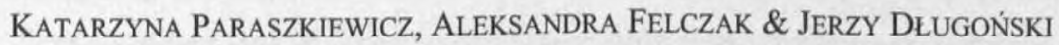

Department of Industrial Microbiology and Biotechnology, University of Łódź, Banacha 12/16, PL90-237, Łódź, Poland

\title{
APPLICATION OF FUNGAL WASTE BIOMASS ORIGINATING FROM STEROID HORMONE MANUFACTURE FOR HEAVY METALS REMOVAL
}

\begin{abstract}
The biomass of Curvularia lunata, used previously for hydrocortisone production, was investigated as a heavy metal biosorbent. Removal of lead, zinc and cadmium ions was evaluated as a function of biosorbent dosages, initial ion concentrations, mode of mycelium modifications, initial $\mathrm{pH}$ of metal solutions and when these metals ions where presented in binary as well in ternary combinations. The results presented in this paper indicate the potential utility of $C$. lunata waste biomass for lead and, to a lower extent, for zinc and cadmium ions removal from acid solutions.
\end{abstract}

Key words: Curvularia lunata, heavy metals, hydrocortisone production, waste biomass

\section{INTRODUCTION}

Pollution of the environment by heavy metals is a serious ecological problem. The main sources of these contaminants are wastes from metallurgical and metal finishing industries, galvanizing, electroplating, battery and chemical manufacturing. After being released into the environment, toxic ions of heavy 
metals are bioaccumulated throughout food chain, which can cause ecological and health hazards (MALIK 2004; IQBAL, EDYVEAN 2004). There are two groups of methods for removing heavy metals from wastewaters: conventional and biological. Conventional processes include physico-chemical reactions such as filtration, precipitation, oxidation, reduction and ion exchange. The mentioned techniques appear to be costly and ineffective in case of effluents with low metal concentration, particularly in the range of $1-100 \mathrm{mg} \mathrm{l}^{-1}$ (SAEED et al. 2005). Due to this fact, biological methods, like biosorption, have focused a great deal of attention, as an attractive alternative for heavy metal removal (AHLUWALIA, GOYAL 2007).

Many studies demonstrated that diverse materials of biological origin such as plants, bacteria, algae, yeast and filamentous fungi can be successfully used to take up heavy metals from aqueous solutions (IQBAL, EDYVEAN 2004; SAEED et al. 2005; Lo et al. 1999; SOARES et al. 2002; HAN et al. 2006; AKSU, DÖNMEZ 2006; MELGAR et al. 2007). Nevertheless, commercial application of sorbents originating from microorganisms may be limited due to the costs involved in the production of biomass. Filamentous fungi and yeast are widely used in a variety of industrial fermentation processes (e.g. production of antibiotics, organic acids, enzymes and in brewery industry). Additionally, since fungal biomass is an abundant by-product and is of little use, it may be an inexpensive source of biomaterial for heavy metal remediation processes. It is well documented that waste biomass derived from fungi of biotechnological importance (mainly species of Aspergillus, Fusarium, Penicillium, Mucor and Saccharomyces) can be used as heavy metal biosorbents (Lo et al. 1999; KAPOOR et al. 1999; JIANLONG et al. 2001; GÖKSUNGUR et al. 2005; PARK et al. 2005; MUNGASAVALLi et al. 2007).

The 11ß-hydroxylation of cortexolone is a transformation widely used in pharmaceutical industry. It is a direct way to obtain hydrocortisone, an effective anti-inflammatory drug as well as an important precursor of other pharmaceutical corticosteroids (FERNANDES et al. 2003). Filamentous fungus Curvularia lunata is one of the most promising cortexolone 11 $\beta$-hydroxylators (PARASZKIEWICZ et al. 1998; LU et al. 2006). To our knowledge, no research has been carried out on the 
heavy metal removal by waste mycelium of $C$. lunata obtained after cortexolone conversion to hydrocortisone.

The aim of the presented study was to investigate the ability of dead biomass of $C$. lunata to remove heavy metals from aqueous solutions. For experiments was chosen the wild strain of $C$. lunata IM 2901 with the confirmed ability of $11 \beta$ hydroxylation of cortexolone (WILMAŃSKA et al. 1992; PARASZKIEWICZ et al. 1998; KANWAL et al. 2001). The basic characterization of heavy metals binding by growing mycelium of this fungus and by its emulsifier had been previously described (PARASZKIEWICZ et al. 2007). Microbial uptake of metals is significantly decreased in wastewaters of low $\mathrm{pH}$. In experiments described in this paper $\mathrm{pH}$ values of metal solutions were from 4 to 6 because we were particularly interested in the possibility of heavy metal removal from acidic wastewaters, without preliminary $\mathrm{pH}$ adjustment.

\section{MATERIALS AND METHODS}

\subsection{Microorganism and maintenance}

The filamentous fungus Curvularia lunata (Wakker) Boedijn IM 2901 from the collection of the Department of Industrial Microbiology and Biotechnology, University of Lodz was used in the study. The fungal strain was maintained on ZT slants (PARASZKIEWICZ et al. 2002) at $4^{\circ} \mathrm{C}$ and transferred at 2-month intervals.

\subsection{Mycelium growth conditions and cortexolone hydroxylation}

Mycelia originating from 10-day-old cultures on ZT slants were suspended in PL-2 medium (PARASZKIEWICZ et al. 2002) and incubated at $28^{\circ} \mathrm{C}$ for $24 \mathrm{~h}$ on a rotatory shaker $(180 \mathrm{rpm})$. First-step preculture $(10 \%)$ was used as inoculum for the second-step of cultivation, conducted in conditions described above. According to the method developed by PARASZKIEWICZ and DeUGoŃsKI (1998), steroid hydroxylase induction was carried out for $6 \mathrm{~h}$ by adding to the 18 -h-old second-step 
preculture cortexolone dissolved in ethanol (final concentration of steroid $0.1 \mathrm{~g} \mathrm{l}^{-1}$ and ethanol in the culture $1 \% \mathrm{v} / \mathrm{v}$ ). The achieved 24-h-old second-step culture (60 $\mathrm{ml}$ ) was introduced into 2l-Erlenmeyer flasks containing $540 \mathrm{ml}$ of the PL-2 medium and supplemented with cortexolone dissolved in ethanol (at final concentration of steroid $1.0 \mathrm{~g} \mathrm{l}^{-1}$ and ethanol in the culture $\left.1 \%(\mathrm{v} / \mathrm{v})\right)$. Final cultures were incubated on a rotatory shaker in conditions described above for 48 hours.

\subsection{Isolation and pretreatment of the fungal biomass}

After fungal growth and cortexolone transformation to the whole 48-h-old culture a mixture of chloroform: acetone (9:1) was added. Steroid extraction was repeated three times. The collected waste biomass was washed several times with deionised water for culture broth and organic solvents removal and then lyophilised. In the next part of the work biomass prepared in this way was referred to as unmodified or waste biosorbent.

In some experiments mycelia modified (pretreated) with ethanol or sodium hydroxide $(\mathrm{NaOH})$ were used. Ethanol treated samples of biosorbent were prepared by suspending $50 \mathrm{~g}$ of wet $C$. lunata biomass in $500 \mathrm{ml}$ of $80 \%$ ethanol. The modification procedure was carried out at room temperature on a rotatory shaker (180 rpm) for 1 hour. After pretreatment procedure, the biomass samples were washed several times with deionised water and then lyophilised. Modification with $\mathrm{NaOH}$ was carried out according to the method described by KAPOOR et al. (1999). $\mathrm{NaOH}$ treated mycelium was prepared by boiling $50 \mathrm{~g}$ of wet biomass in $500 \mathrm{ml}$ of $0.5 \mathrm{~N} \mathrm{NaOH}$ solution for $15 \mathrm{~min}$. Biomass pretreated with sodium hydroxide was washed with deionized water until the $\mathrm{pH}$ reached the near neutral range $(\mathrm{pH} 6.8$ 7.2 ) and then it was lyophilised.

\subsection{Metal sorption studies}

The standard stock solutions $(0.2 \mathrm{M})$ were prepared by dissolving the respective nitrate salts of the metals in deionised water. The $\mathrm{pH}$ of working metal solutions $(0.2 \mathrm{M})$ were adjusted to required values $(4.0 ; 5.0$ or 6.0$)$ with $0.1 \mathrm{M} \mathrm{HCl}$. 
Sorption experiments were carried out in $250 \mathrm{ml}$ Erlenmeyer flasks containing $100 \mathrm{ml}$ of 0.2 or $5.0 \mathrm{mM}$ single metal solution and lyophilized waste biomass (at a final concentration of 0.5 or $1.0 \mathrm{~g} \mathrm{l}^{-1}$ ). For studies on metal biosorption from binary and ternary solutions, the concentration of each metal ions in the solution was $0.2 \mathrm{mM}$. The samples were incubated on a rotatory shaker (180 rpm), at $28^{\circ} \mathrm{C}$, for 2 hours. Then metal-loaded mycelium was separated by filtration (Millipore filters with $0.45 \mu \mathrm{m}$ pore size) and dried at $105^{\circ} \mathrm{C}$ to constant weight. Metal concentration in the mycelium samples was analyzed in a Varian atomic absorption spectrometer (Spectra 300) according to the method described by SŁABA and DLUGOŃSKI (2004). The efficiency of metal ions removal was calculated based on the weight of metal ions contained in the biomass per flask divided by the initial metal ions weight in the solution per $100 \%$. All data represent the mean of three independent experiments. An average standard deviation was calculated.

\section{RESULTS}

\subsection{Comparison of the effectiveness of different heavy metals removal by waste} biomass of $C$. lunata

In the first part of the work the removal of seven various heavy metals was studied. Metal uptake was conducted by unmodified mycelium samples (at a concentration of $\left.0.5 \mathrm{~g} \mathrm{l}^{-1}\right)$ suspended in single metal solutions $(0.2 \mathrm{mM})$, adjusted to $\mathrm{pH}$ 4. The removal efficiency for $\mathrm{Pb}^{2+}, \mathrm{Zn}^{2+}, \mathrm{Cd}^{2+}, \mathrm{Cu}^{2+}, \mathrm{Cr}^{2+}, \mathrm{Ni}^{2+}$ and $\mathrm{Co}^{2+}$ was found to be $46.2,30.7,27.0,22.6,18.9,11.8$ and 2.4\%, respectively (Fig. 1). Because the highest removal efficiency occurred in $\mathrm{Pb}^{2+}, \mathrm{Zn}^{2+}$ and $\mathrm{Cd}^{2+}$ solutions, these three metals were selected for further investigations.

3.2. Effect of the biosorbent dosage and the initial concentration of lead, zinc and cadmium on the removal efficiency

Efficiency of $\mathrm{Pb}^{2+}, \mathrm{Zn}^{2+}$ and $\mathrm{Cd}^{2+}$ removal was examined as a function of $C$. lunata biomass dosage $\left(0.5\right.$ and $\left.1.0 \mathrm{~g}^{-1}\right)$ as well as the initial concentration of heavy 
metal $(0.2$ and $5.0 \mathrm{mM})$. Metal uptake was conducted by unmodified biosorbent samples suspended in single $\mathrm{Pb}^{2+}, \mathrm{Zn}^{2+}$ or $\mathrm{Cd}^{2+}$ solution, adjusted to $\mathrm{pH}$ 4. The removal efficiency of heavy metal ions was improved almost twice in the presence of a higher dose of biomass (Fig. 2). Moreover, as shown in Fig. 3, with the decrease in the initial concentration of heavy metal (from 5.0 to $0.2 \mathrm{mM}$ ) a significant increase in $\mathrm{Pb}^{2+}, \mathrm{Zn}^{2+}$ and $\mathrm{Cd}^{2+}$ removal efficiency was achieved (from 7.0, 3.8 and $3.2 \%$ to $81.8,55.9$ and $47.4 \%$, respectively). In conclusion, conditions: $1 \mathrm{~g} \mathrm{l}^{-1}$ of fungal biomass and heavy metal ions at the initial concentration of $0.2 \mathrm{mM}$, promoting the removal of lead, zinc and cadmium were used in the next parts of the study.

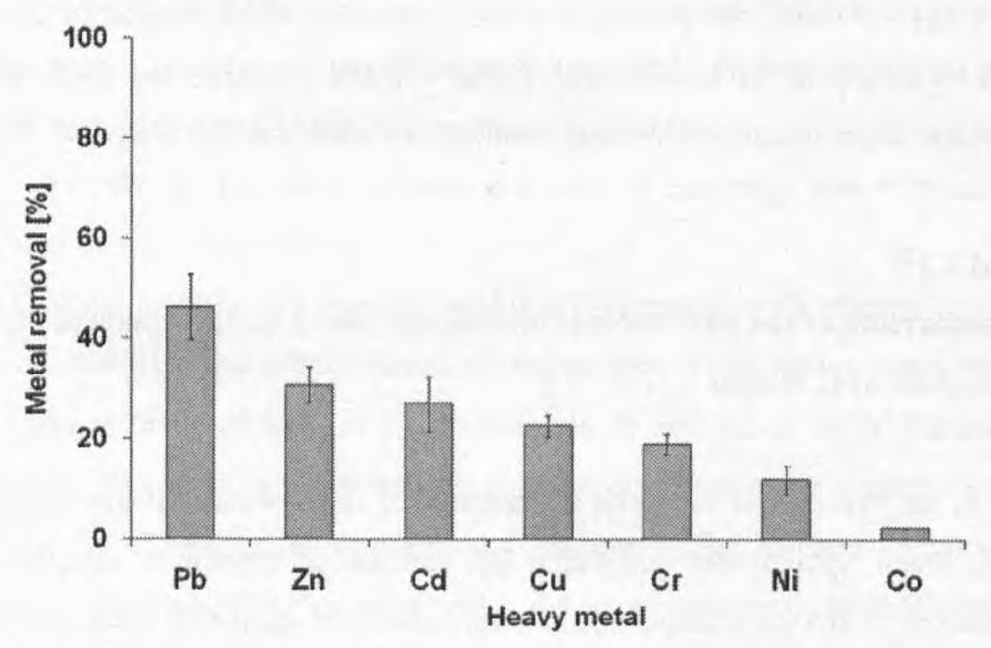

Fig. 1: Removal efficiency of $\mathrm{Pb}, \mathrm{Zn}, \mathrm{Cd}, \mathrm{Cu}, \mathrm{Cr}, \mathrm{Ni}$ and $\mathrm{Co}$ from single metal solutions at $\mathrm{pH} 4$ by waste biomass of $C$. lunata at a concentration of $0.5 \mathrm{~g} \mathrm{l}^{-1}$, suspended in single metal solutions $(0.2 \mathrm{mM})$. Data are mean $\pm \mathrm{SD}(\mathrm{n}=3)$

3.3. Effect of waste biomass modification on lead, zinc and cadmium removal efficiency

Effectiveness of heavy metal removal (from single metal solutions, at $\mathrm{pH}$ 4) by unmodified, $\mathrm{NaOH}$ pretreated and ethanol pretreated biomass samples of $C$. lunata reached for $\mathrm{Pb}^{2+}: 81.8 ; 30.5$ and $3.7 \%$, for $\mathrm{Zn}^{2+}: 55.9 ; 54.5$ and $50.7 \%$ and for 


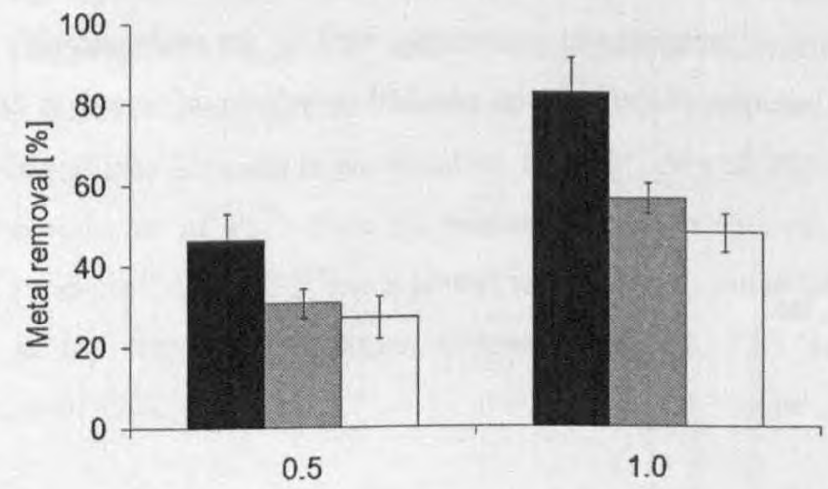

Biosorbent concentration [g/l]

Fig. 2: The influence of biosorbent dosage on $\mathrm{Pb}^{2+}, \mathrm{Zn}^{2+}$ and $\mathrm{Cd}^{2+}$ removal efficiency from single metal solutions $(0.2 \mathrm{mM})$ at $\mathrm{pH} 4$. Black bars $-\mathrm{Pb}$; grey bars - Zn; white bars $-\mathrm{Cd}$. Data are mean $\pm \mathrm{SD}(\mathrm{n}=3)$

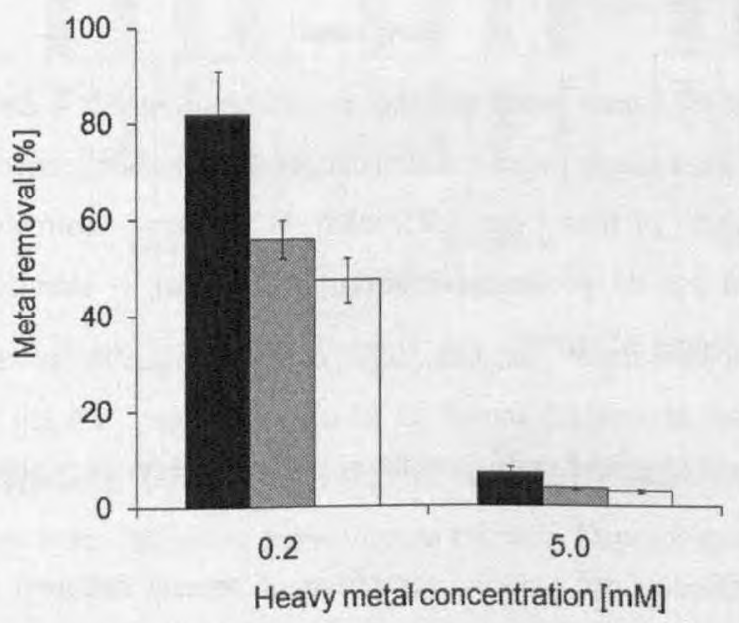

Fig. 3: The influence of the initial concentration of $\mathrm{Pb}^{2+}, \mathrm{Zn}^{2+}$ and $\mathrm{Cd}^{2+}$ on these metal ions removal efficiency from single metal solutions at $\mathrm{pH} 4$, by waste biomass of $C$. lunata at a concentration of $1 \mathrm{~g} \mathrm{l}^{-1}$. Black bars $-\mathrm{Pb}$; grey bars $-\mathrm{Zn}$; white bars - Cd. Data are mean \pm SD $(n=3)$ 
$\mathrm{Cd}^{2+}: 47.4,45.2$ and $45 \%$, respectively (Fig. 4). The data mentioned above revealed that both chemical pretreatment procedures used in the study strongly decreased $\mathrm{Pb}^{2+}$ sorption capacity of the biomass and had only little influence on $\mathrm{Zn}^{2+}$ or $\mathrm{Cd}^{2+}$ removal.

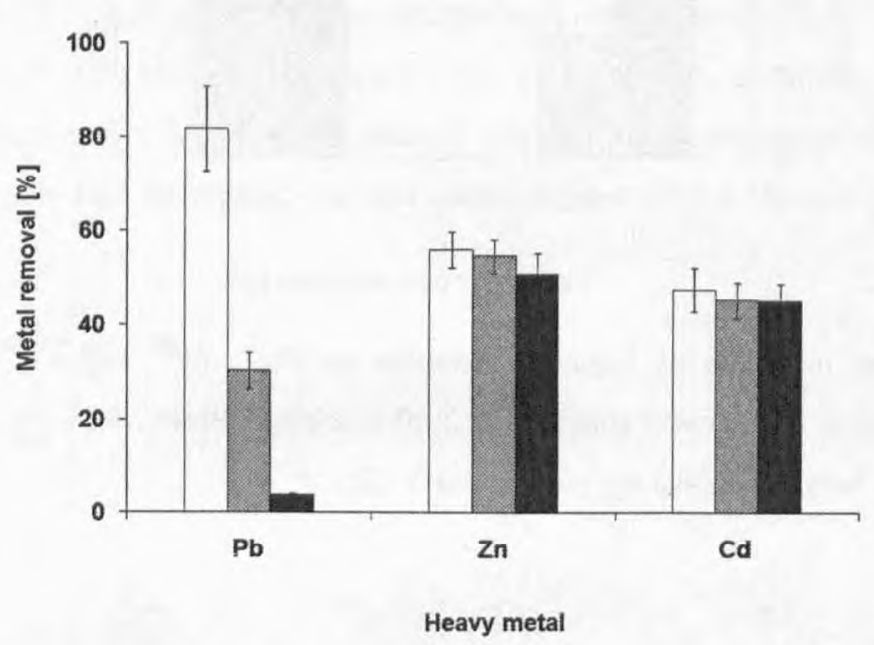

Fig. 4: Influence of $C$. lunata waste biomass modification on $\mathrm{Pb}^{2+}, \mathrm{Zn}^{2+}$ and $\mathrm{Cd}^{2+}$ removal efficiency from single metal solutions at $\mathrm{pH} 4$ (biosorbent concentration $1 \mathrm{~g}$ $\mathrm{I}^{-1}$; initial concentration of heavy metal $0.2 \mathrm{mM}$ ). White bars - untreated biomass; grey bars $-0.2 \mathrm{M} \mathrm{NaOH}$ pretreated biomass; black bars - ethanol pretreated biomass. Data are mean $\pm \mathrm{SD}(\mathrm{n}=3)$

\subsection{Removal of lead, zinc and cadmium from binary and ternary solutions}

Industrial effluents are usually composed of several different metal ions. Therefore removal of $\mathrm{Pb}^{2+}, \mathrm{Zn}^{2+}$ and $\mathrm{Cd}^{2+}$ from single metal solutions was compared with the efficiency of this process recorded for binary as well as ternary metal combinations. Results presented in Fig. 5 revealed that biosorption capacity of zinc and cadmium ions decreased approximately by 25 and $30 \%$, respectively when these two metals were presented together. The presence of $\mathrm{Pb}^{2+}$ significantly interfered in the sorption of zinc and cadmium ions. About 3-fold decrease in zinc removal 
efficiency was detected from binary $\left(\mathrm{Zn}^{2+}+\mathrm{Pb}^{2+}\right)$ and ternary $\left(\mathrm{Zn}^{2+}+\mathrm{Pb}^{2+}+\mathrm{Cd}^{2+}\right)$ systems as compared with single $\mathrm{Zn}^{2+}$ solution (respectively 17.2 , $19.5 \%$ contrasted with $55.9 \%$ ). Similar strong decline of removal efficiency was noted for cadmium when these metal ions occurred in combination with $\mathrm{Pb}^{2+}$ or with $\mathrm{Pb}^{2+}$ plus $\mathrm{Zn}^{2+}$. In contrast, the removal of $\mathrm{Pb}^{2+}$ from all examined metal solutions: $\left(\mathrm{Pb}^{2+}+\mathrm{Zn}^{2+}\right)$, $\left(\mathrm{Pb}^{2+}+\mathrm{Cd}^{2+}\right)$ and $\left(\mathrm{Pb}^{2+}+\mathrm{Zn}^{2+}+\mathrm{Cd}^{2+}\right)$ was almost as efficient as noted for the sorption conducted in the single $\mathrm{Pb}^{2+}$ solution (respectively 79.2, 72.1 and $80.6 \%$ in comparison to $81.9 \%$ ).

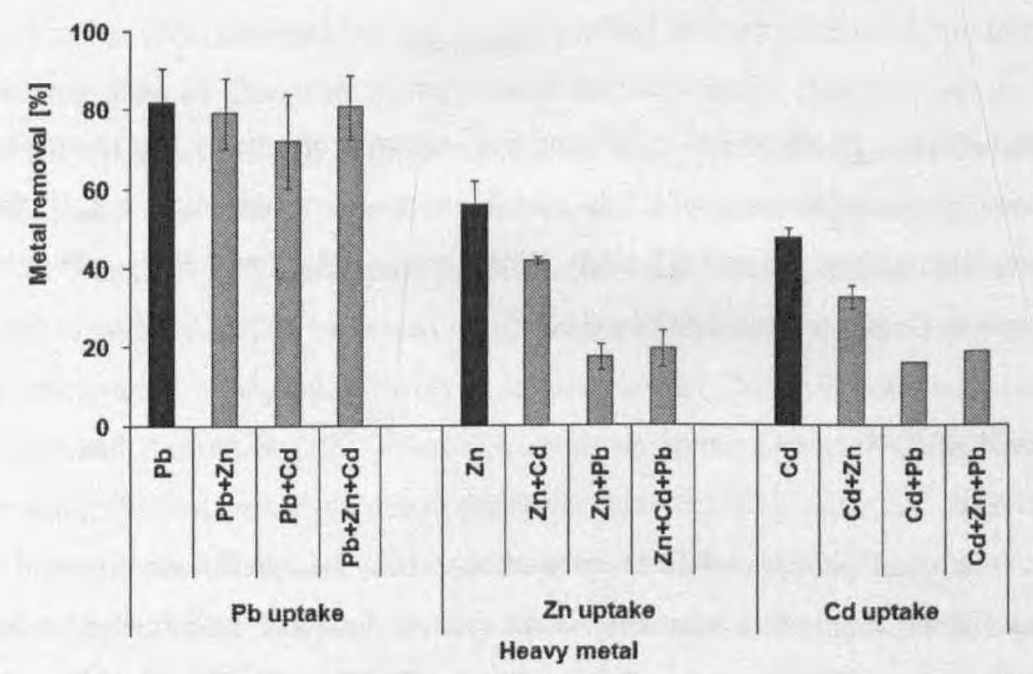

Fig. 5: Removal efficiency of $\mathrm{Pb}^{2+}, \mathrm{Zn}^{2+}$ and $\mathrm{Cd}^{2+}$ from binary and ternary metal solutions at $\mathrm{pH} 4$ by waste biomass of $C$. lunata (biosorbent concentration $1 \mathrm{~g} \mathrm{l}^{-1}$; initial concentration of each heavy metal $0.2 \mathrm{mM}$ ). Black bars - single metal solution; grey bars - binary or ternary metal mixture. Data are mean $\pm \operatorname{SD}(n=3)$

\subsection{The effect of $\mathrm{pH}$ on lead, zinc and cadmium removal}

As shown in Fig. 6 the uptake of $\mathrm{Pb}^{2+}, \mathrm{Zn}^{2+}$ and $\mathrm{Cd}^{2+}$ conducted in single metal solutions occurred to be $\mathrm{pH}$ dependent. The increase in metal solution $\mathrm{pH}$ value from 4 to 6 accelerated the removal efficiency of $\mathrm{Pb}^{2+}, \mathrm{Zn}^{2+}$ and $\mathrm{Cd}^{2+}$ from $81.9,55.9$ and $47.4 \%$ respectively to 94.075 .4 and $62.6 \%$. 


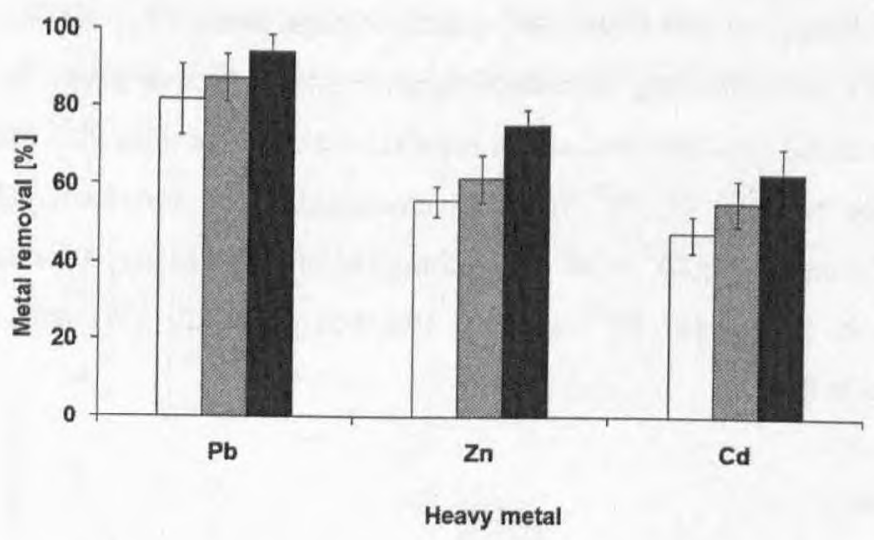

Fig. 6: Influence of $\mathrm{pH}$ on $\mathrm{Pb}^{2+}, \mathrm{Zn}^{2+}$ and $\mathrm{Cd}^{2+}$ removal efficiency from single metal solutions by waste biomass of $C$. lunata (biosorbent concentration $1 \mathrm{~g} \mathrm{l}^{-1}$; initial concentration of heavy metal $0.2 \mathrm{mM}$ ). White bars $-\mathrm{pH} 4$; grey bars $-\mathrm{pH} 5$; black bars $-\mathrm{pH}$ 6. Data are mean $\pm \mathrm{SD}(\mathrm{n}=3)$

\section{DISCUSSION}

The dead biomass of filamentous fungus Curvularia lunata obtained after hydrocortisone production via cortexolone conversion was examined as a heavy metal biosorbent. Among seven heavy metals $(\mathrm{Pb}, \mathrm{Zn}, \mathrm{Cd}, \mathrm{Cu}, \mathrm{Cr}, \mathrm{Ni}$ and $\mathrm{Co}$ ) tested, the mycelial biomass exhibited the highest removal efficiency for $\mathrm{Pb}^{2+}, \mathrm{Zn}^{2+}$ and $\mathrm{Cd}^{2+}$. A similar order of uptake intensity $(\mathrm{Pb}>\mathrm{Zn}>\mathrm{Cd}>\mathrm{Ni})$ was reported by $\mathrm{YAN}$ and VIRARAgHAVAN (2003) for dead mycelium of Mucor rouxii as a heavy metal biosorbent. The higher affinity of $C$. lunata mycelium to lead than to other heavy metal ions is in line with many studies on diverse fungal biosorbents (IQBAL, EDYVEAN 2004; MELGAR et al. 2007; KAPOOR et al. 1999; GÖKSUNGUR et al. 2005; SŁABA, DŁUGOŃSKI 2004). Three strains of filamentous fungi: Curvularia lunata IM 2901 (the same as used in this work), Curvularia tuberculata IM 4417 and Paecilomyces marquandii IM 6003 previously tested by us, during the growth in liquid medium also accumulated lead with higher efficiency than zinc and cadmium 
(PARASZKIEWICZ et al. 2007). According to ZoubOULIS et al. (1999) a greater sorption of $\mathrm{Pb}^{2+}$ than of many other heavy metals (e.g. $\mathrm{Zn}^{2+}, \mathrm{Cd}^{2+}, \mathrm{Ni}^{2+}$ or $\mathrm{Cu}^{2+}$ ) may be partially explained by a high stability constant for $\mathrm{Pb}^{2+}$ binding to the ligands of fungal surface.

The possibility to enhance heavy metals removal as a result of physical or chemical pretreatment of plant and microbial biosorbents is pointed out by many researchers (SAEED et al. 2005; KAPOOR et al. 1999; GÖKSUNGUR et al. 2005; Mungasavalli et al. 2007). The improvement of metal binding properties of modified biosorbents could be explained by the increase in metal ions access to the metal binding sites, attributed to the cleansing effect of the agents used, modification of binding sites or changing in the overall surface charge (KAPOOR et al. 1999; GÖKSUNGUR et al. 2005). Data presented in this paper revealed that additional modifications of $C$. lunata mycelium with $\mathrm{NaOH}$ or ethanol did not enhance either $\mathrm{Pb}^{2+} \mathrm{Zn}^{2+}$ or $\mathrm{Cd}^{2+}$ sorption capacity. The same, experimental results indicate that ethanol as well as $\mathrm{NaOH}$ treatment of $\mathrm{C}$. lunata biomass caused the removal or at least inactivation of the sites involved in lead uptake. Nevertheless, according to PURANIK and PAKNIKAR (1997) findings, while using the modified biosorbent on a large scale, the cost escalation due to pretreatment needs to be taken into account.

Sorption of lead, zinc and cadmium by $C$. lunata waste biomass was also examined by us when heavy metals ions where presented in binary as well in ternary combinations. Efficiency of the mycelium to remove lead ions from binary $\left(\mathrm{Pb}^{2+}+\mathrm{Zn}^{2+}\right.$ or $\left.\mathrm{Pb}^{2+}+\mathrm{Cd}^{2+}\right)$ as well as from ternary $\left(\mathrm{Pb}^{2+}+\mathrm{Zn}^{2+}+\mathrm{Cd}^{2+}\right)$ metal solutions occurred to be similar to the one achieved when $\mathrm{Pb}^{2+}$ was presented alone. Nevertheless, the presence of lead ions significantly decreased the sorption of $\mathrm{Zn}^{2+}$ and $\mathrm{Cd}^{2+}$. Our results are in agreement with those obtained by KAPOOR et al. (1999) and indicate that antagonic interactions between various heavy metals may occur in multiple metal solutions. The drop in the sorption of $\mathrm{Zn}^{2+}$ and $\mathrm{Cd}^{2+}$ from two- and three-metal combinations indicates a competition among $\mathrm{Zn}, \mathrm{Cd}$ and $\mathrm{Pb}$ ions for the same binding sites presented on the surface of $C$. lunata biomass. Greater affinity of lead than of two other examined heavy metals to the biosorbent was probably caused 
by a larger ion size of $\mathrm{Pb}^{2+}$ in comparison to $\mathrm{Zn}^{2+}$ and $\mathrm{Cd}^{2+}(0.112,0.074$ and 0.097nm, respectively) (ANGYAL 1989).

In the present studies the uptake of heavy metals by $C$. lunata mycelium was found to be influenced by the initial $\mathrm{pH}$ of metal solution and rose due to the increase in $\mathrm{pH}$ value. The removal of $\mathrm{Pb}^{2+}, \mathrm{Zn}^{2+}$ and $\mathrm{Cd}^{2+}$ from single metal solutions reached at $\mathrm{pH} 6$ the highest levels of $94.0,75.4$ and $62.6 \%$, respectively. According to PURANIK and PAKNIKAR (1997) lead and zinc uptake by waste biomass of $S$. cinnamoneum was also influenced by $\mathrm{pH}$ of the metal solution. The $\mathrm{pH}$ range (5.0-6.0) established in that study as the optimum for zinc uptake fits well with our results, but maximum the lead removal determined at $\mathrm{pH} 4.5$ occured to be lower than for $C$. lunata biosorbent. Nevertheless, the $\mathrm{pH}$ of the lead solution increased from 4.0 to 6.5 during the adsorption process conducted by S. cinnamoneum. At $\mathrm{pH}$ 6 the maximum capacity of lead uptake was estimated with mycelium of Mucor rouxii as a metal biosorbent (Lo et al. 1999). SAY et al. (2001) used biomass of filamentous fungus Phanerochaete chrysosporium for $\mathrm{Pb}^{2+}$ removal and also determined the optimum $\mathrm{pH}$ value for biosorption as 6.0. It has been commonly agreed that $\mathrm{pH}$ value of metal solution can strongly influence metal uptake intensity of biosobents (IQBAL, EdYVEAN 2004; MELGAR et al. 2007; GÖKSUNGUR et al. 2005; Mungasavalli et al. 2007). Due to the increased hydrogen $\left(\mathrm{H}^{+}\right)$and hydronium $\left(\mathrm{H}_{3} \mathrm{O}^{+}\right)$concentrations at the high acidic $\mathrm{pH}$ solution, these ions compete effectively with metal ions in binding to negatively charged groups on the biosorbent surface. Consequently, the increase in heavy metal uptake with increasing $\mathrm{pH}$ could be attributed to less ionic competition (PURANIK, PAKNIKAR 1997).

From the results presented in this study it can be concluded that $C$. lunata biomass, a potential waste by-product from hydrocortisone manufacture, could be considered as an inexpensive material for lead and, to a lower extent, zinc and cadmium ions removal from aqueous effluents.

\section{Acknowledgements}

This study was supported by the University of Lodz grant (No. 505/440). 


\section{REFERENCES}

Ahluwalia, S. S., Goyal, D. 2007. Microbial and plant derived biomass for removal of heavy metals from wastewater. Bioresour. Technol. 98: 2243-2257.

AKSU, Z., DöNMEZ, G. 2006. Binary biosorption of cadmium(II) and nickel(II) onto dried Chlorella vulgaris: Co-ion effect on mono-component isotherm parameters. Process. Biochem. 41: 860-868.

ANGYAL, S. J. 1989. Complexes of metal cations with carbohydrates in solution. Ad. Carbohydr. Chem. Biochem. 47: 1-43.

Fernandes, P., Cruz, A., Angelova, B., Pinheiro, H. M., Cabral, J. M. S. 2003. Microbial conversion of steroid compounds: recent developments. Enzyme Microb. Technol. 32: 688-705.

GÖKSUNGUR, Y., ÜREN, S., GÜVENČ, U. 2005. Biosorption of cadmium and lead ions by ethanol treated waste baker's yeast biomass. Bioresour. Technol. 96: 103-109.

HAN, R., LI, H., LI, Y., ZHANG, J., XIAO, H., SHI, J. 2006. Biosorption of copper and lead ions by waste beer yeast. J. Hazard. Mater. B. 137: 1569-1576.

IQBAL, M., EDYVEAN, R. G. J. 2004. Biosorption of lead, copper and zinc ions on loofa sponge immobilized biomass of Phanerochaete chrysosporium. Miner. Eng. 17: 217-223.

JiAnlong, W., Xinmin, Z., DeCAI, D., Ding, Z. 2001. Bioadsorption of lead(II) from aqueous solution by fungal biomass of Aspergillus niger. J. Biotechnol. 87: $273-277$.

Kanwal, A., Paraszkiewicz, K., Dlugoński, J. 2001. Transformation of Curvularia lunata IM 2901 with pAN7-1 influences selected physiological properties of the fungus. Microbios. 104: 27-38.

Kapoor, A., Viraraghavan, T., Cullimore, D. R. 1999. Removal of heavy metals using the fungus Aspergillus niger. Bioresour. Technol. 70: 95-104.

Lo, W., ChUA, H., LAM, K.H. BI, S.P. 1999. A comparative investigation on the biosorption of lead by filamentous fungal biomass. Chemosphere 39: 2723-2736. 
LU, W. Y., Du, L.X., WANG, M., WEN, J.P., SUN, B., GUO, Y-W. 2006. Effect of two-steps substrate addition on steroids $11 \beta$-hydroxylation by Curvularia lunata CL-114. Biochem. Eng. J. 32: 233 238.

MALIK, A. 2004. Metal bioremediation through growing cells. Environ. Int. 30,: 261-278.

Melgar, M. J., Alonso, J., Garcia, M. A. 2007. Removal of toxic metals from aqueous solutions by fungal biomass of Agaricus macrosporus. Sci. Total. Environ. 385: 12-19.

Mungasavalli, D. P., Viraraghavan, T., Jin, Y. 2007. Biosorption of chromium from aqueous solutions by pretreated Aspergillus niger: Batch and column studies. Colloids Surf. A. Physicochem. Eng. Asp. 301: 214-223.

PARAsZKIEWICZ, K., DlUgoŃSKI, J. 1998. Cortexolone 11ß-hydroxylation in protoplasts of Curvularia lunata. J. Biotechnol. 65: 217-224.

Paraszkiewicz, K., Frycie A., Slaba M., DŁUgońSKi J. 2007. Enhancenment of emulsifier production by Curvularia lunata in cadmium zinc and lead presence. Biometals 20: 797-805.

ParaszkiewicZ, K., Kanwal, A., DlugońSKI, J. 2002. Emulsifier production by steroid transforming filamentous fungus Curvularia lunata. Growth and product characterization. J. Biotechnol. 92: 287-294.

PARK, D., YUN, Y.S., PARK, J. M. 2005. Use of dead fungal biomass for the detoxification of hexavalent chromium: screening and kinetics. Process. Biochem. 40: 2559-2565.

PURANIK, P. R., PAKNIKAR, K. M. 1997. Biosorption of lead and zinc from solutions using Streptoverticillium cinnamoneum waste biomass. J. Biotechnol. 55: 113124.

SaeEd, A., IQBal, M., AKhtar, M. W. 2005. Removal and recovery of lead(II) from single and multimetal $(\mathrm{Cd}, \mathrm{Cu}, \mathrm{Ni}, \mathrm{Zn})$ solutions by crop milling waste (black gram husk). J. Hazard. Mater. 117: 65-73.

SAY, R., DENIZLI, A., ARICA, M. Y. 2001. Biosorption of cadmium(II), lead(II) and copper(II) with the filamentous fungus Phanerochaete chrysosporium. Bioresour. Technol. 76: 67-70. 
SŁaBA, M., DŁugoński, J. 2004. Zinc and lead uptake by mycelium and regenerating protoplasts of Verticillium marquandii. World J.Microbiol. Biotechnol. 20: 323-328

Soares, E. V., De coninck, G., Duarte, F., Soares, H. 2002. Use of Saccharomyces cerevisiae for $\mathrm{Cu}^{2+}$ removal from solution: the advantages of using a flocculent strain. Biotechnol. Lett. 24: 663-666.

WilmańSKa, D., Milczarek, K., Rumijowska, A., Bartnicka, K., SedlaczeK, L. 1992. Elimination of by-products in 11 $\beta$-hydroxylation of Substance $\mathrm{S}$ using Curvularia lunata clones regenerated from NTG-treated protoplasts. Appl. Microbiol. Biotechnol. 37: 626-630.

Yan, G., ViraraghaVAN, T. 2003. Heavy-metal removal from aqueous solution by fungus Mucor rouxii. Water. Res. 37: 4486-4496.

Zouboulis, A., Rousou, E. G., Matis, K.A., Hancock, J. C. 1999. Removal of toxic metals from aqueous mixtures. J. Chem. Technol. Biotechnol. 74: 429-436. 